\title{
Izcilā lietuviešu antropologa Gintauta Česņa piemiņai
}

\author{
Rita Grāvere
}

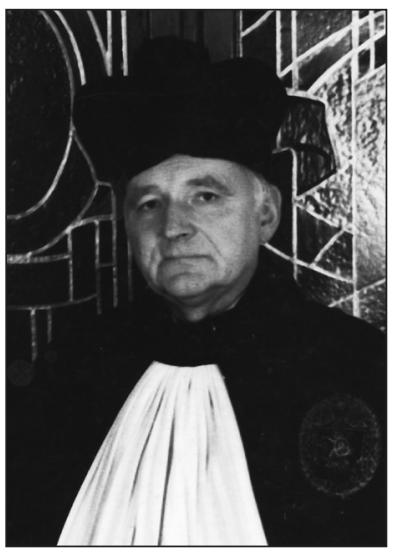

2009. gada oktobrī miris lietuviešu anatoms un antropologs Gintauts Česnis. Dzimis 1940. gada 23. aprīlī Žemaitijā, Rasein̦os. 1963. gadā beidzis Viḷnas Universitātes Medicīnas fakultāti, viňš savu dzivi saistīja ar Viḷnas Universitātes Anatomijas katedru: no 1974. gada - docents, no 1988. gada - profesors un katedras vadītājs. Lielā mērā pateicoties tieši viņa pūlēm, katedra laika gaitā pārtapa par Anatomijas, histologijas un antropologijas katedru.

Atskatoties Lietuvas antropologijas vēsturē, tā bija iznācis, ka pirms Otrā pasaules kara tik sekmīgi aizsākusies antropolog̣iskā pētniecība Lietuvā pēc kara aprima un ilgus gadus nebija arī pètnieka, kas ar to nodarbotos.

Savukārt Latvijā pēc kara sekmīgi uzsāktie antropologíiskie pētijumi baltu senvēsturē, kuru pamatā bija galvenokārt arheoloǵiskajos izrakumos iegūtais kranioloğiskais materiāls, prasît prasijās pēc papildu argumentiem no baltu teritorijas pamatareāla Lietuvā. Tolaik pētnieku rīcībā bija tikai viena kranioloǵiska sērija no Lietuvas vidusdal̦as 2.-4. gs. uzkalniniem. Šeit apbedīto savdabīgais fiziskais tips maz saistìjās ar 10.-12. gs. masīvajām platsejainajām baltu ciltīm, kādas mēs pazinām Latvijas teritorijā. Lietuva kḷuva par savdabīgu atslēgu baltu vēstures durvīs.

Atceros, tas bija 70. gadu pašā sākumā, kad Rīgā, toreizējā Arheoloǵijas un antropologiijas nodạ̄ā, no Viḷnas ieradās divi jauni cilvēki, un viens no viṇiem arheologs V. Urbanavičs - profesori R. Denisovu iepazīstināja ar savu līdzbraucēju kā anatomu, kas nodomājis turpmāk pievērsties antropologijai, kādēḷ arī bija ieradies, lai iepazìtos un paaugstinātu savu kvalifikāciju. Tomēr, kā vēlāk izrādījās, 


\section{Izcilā lietuviešu antropologa G. Česņa pieminai}

savu antropologa ceḷamaizi viņ̌̌ saṇēma no citas antropologes - no izcilās krievu pètnieces T. Aḷeksejevas.

Nākamreiz mēs tikāmies 70. gadu vidū Lietuvas morfologu sanāksmē Kauñā. Bet pēc tam Latvijas un Lietuvas antropologu celi jau gāja roku rokā. G. Češña padarìtais lietuviešu antropolog̣ijā ir nozīmīgākais veikums pēckara Lietuvas antropologijā, un tikpat nozīmīgs tas ir arī Baltijas antropologijas kontekstā.

Viņa ienākšana antropolog̣ijā nebija nejauša. Jau pirms pievēršanās baltu tautu etniskajai antropologijai viņš bija ieinteresējies par šîs nozares sākumiem Lietuvā un nedaudz pastrādājis pie bērnu fiziskās antropolog̣ijas. Tomēr galvenā G. Češņa mūža mīlestība izrādijās baltu tautu etniskā antropologija.

1974. gadā parādijās viņa pirmā publikācija šai jomā, veltīta Lietuvas 14.-17. gs. lietuviešu antropolog̣ijai. Tā kā Lietuvā vēl ilgu laiku nebija 1. g. t. baltu kraniolog̣iskā materiāla, tad G. Česnis aprakstīja viduslaiku materiālu pēc vairākām antropologiiskām programmām - kraniolog̣iskās, diskrēti variējošām pazīmēm u. c. Balstoties viduslaiku materiālā, viņš pirmais Baltijā uzsāka vēsturiskās demogrāfijas problēmu izpēti. Viṇa iespaidā zobu antropolog̣iskai izpētei pievērsās I. Papreckiene (Baḷčuniene), mana nākamā kolēge, šodien liela institūta direktore, kuras doktorants 2006. gadā papildināja savu doktora darbu ar materiāliem no Jēkaba Prīmaņa Anatomijas muzeja Rìgā.

Apbrīnojama bija profesora Česņa enerğija, ar kādu viņš uzņēmās pārbaudìt un savākt jaunus antropologiskos datus no blakusesošajām valstīm. Pateicoties viṇa pūlēm, 1980. gadā strauji papildinājās 2.-4. gs. kapulauku materiāls. 1981. gadā viņš pirmoreiz publicēja Lietuvā un Polijā atrasto jātvingu galvaskausu materiālu. Prūsijā G. Česnis atrada senaizmirsto akmenslaikmeta cilvēku antropolog̣iskās liecibas. 20. gs. 80. gados Lietuvā atsegtie 1. g. t. kapulauki, kuru kraniolog̣isko un osteologisko materiālu izmērīja un izvērtēja G. Česnis, lika pilnīgi citādi un pa jaunam paskatīties uz baltu etnisko vēsturi. Kur nu vēl 80. gadu otrajā pusē Lietuvā pirmoreiz atraktie akmenslaikmeta cilvēki (Kretonas, Doṇkalnis)! Beidzot pētniekiem radās unikāla iespēja izsekot teritorijas apdzīvotībai no senākā akmenslaikmeta līdz 17.-18. gadsimtam. Tas viss rada savu atspogulojumu G. Česṇa doktora disertācijā par Lietuvas seno iedzīvotāju antropolog̣iju, kas sekmīgi aizstāvēta Maskavā 1985. gadā.

Materiāla daudzveidība rosināja vadošos Baltijas antropologus vispārināt datus un izveidot jaunas, šo materiālu aptverošas teorijas. Tā pamazām pa šuvēm ira un juka ārā kādreizējā Igaunijas profesora H. Mooras vēl 20. gs. 50. gados izstrādātā autohtonā baltu attīstības teorija.

Vispārinot un izvērtējot šos materiālus, abiem Baltijas vadošajiem antropologiem R. Denisovai un G. Česnim radās dažādas, reizēm pat pilnīgi pretējas pēc sava skaidrojuma, teorijas. Šai ziņā nozīmīgs ir pēdējais baltu un Baltijas somu izcelsmei un etnoǵenētiskiem procesiem veltītais krājums, kas iznāca 1990. gadā Rīgā. Abi krājuma ievadraksti diezgan dažādi skaidro vairāku baltu cilšu etnisko vēsturi, jo īpaši kuršu, kuru kaulu materiāls ir visniecīgākais gan Lietuvā, gan Lat- 
vijā. Tomēr jābūt milzīgai drosmei, lai sēlus, kuršus un lỉbiešus apvienotu vienā morfologisko formu lokā, kā to darīja prof. G. Česnis, turklāt tas lielā mērā nesakrita, nesabalsojās ar citu morfoloǵisko sistēmu, it īpaši odontoloğijas, datiem.

Jebkurā gadỉjumā kopējā Baltijas sadarbība, ko no lietuviešu puses sekmīgi ìstenoja G. Cesnis, nesa aug̣̣us. Tās bija gan baltu konferences, gan kopējs krājums, gan vienkāršas darba tikšanās kvalifikācijas paaugstināšanai. Mēs tikāmies daudzreiz gan Viḷnā, gan Rīgā un Maskavā, pārrunājot ne tikai zinātnes, bet arī politiskos un kultūras notikumus. Viena no tādām sanāksmēm bija 80. gados, kad Polijā apspieda "Solidaritāti", un mēs visi tolaik bijām nacionālisti šā vārda labākajā nozīmē.

Palikusi atmiņā arī kāda cita saruna, kad, pārrunājot latviešu un lietuviešu tautas likteņus, viņš man sacīja: ".. mums (lietuviešiem) ir augstāks pašcieņas līmenis, jo mums vēsturē ir bijusi valsts, un tāpēc mēs esam drosmīgāki un pašapzinīgāki par jums". Tad es arī uzzināju par viṇa tēva traǵisko likteni 1945. gadā un visu to sāpi, ko Gintautas nesa sevī un vēlāk iemiesoja savos antropoloǵiskajos pētijumos. Viņš mīlēja Lietuvu, lepojās ar Viḷnu un tās universitāti, ar lietuviešu, īpaši jau žemaišu, vēsturi. Viņam piemita skaista balss: tā bija neaizmirstamā 80 . gadu beigu zobu antropologu (dontologu) tikšanās Vil̦nnā, kad prof. Česnis mūs priecēja ar dažādu tautu tautasdziesmām. Viņa plašais redzesloks un kultūra un ippaši jau folkloras mīlestība ierindoja viṇu izcilāko sava laika Lietuvas inteliǵences pārstāvju vidū.

Pēdējo reizi mēs tikāmies jau brīvvalsts laikā Rīgā, kad vecajā, mịlajā Anatomikumā tika atzīmēta V. Deruma 100 gadu jubilejas konference, un Anatomijas muzeja vadītājas R. Lindbergas aicināts, viņš uzstājās ar referātu un vadīja sēdi. 1999. gadā iznāca arī viṇa un kolēges I. Bal’čiūnienes monogrāfija "Senās Lietuvas antropoloǵija". 2005. gadā dienasgaismu ieraudzijja kopējs lietuviešu veikums "No kurienes mēs nākam" par lietuviešu izcelsmi; tā antropoloǵisko daļu uzrakstija profesors G. Česnis.

Ir pagājis laiks, mainījušies arī pētniecības virzieni antropolog̣ijā, mūsu kādreiz tik kvēli aizstāvētā un padomju laikos zināmā mērā līdz pasivai pretošanās formai nonākusī etniskā antropolog̣ija sāk nogrimt aizmirstībā. Tomēr padarītais paliek, un šie senie mūsu vēstures un dzīves liecinieki, ko pētniecības procesā esam izcēluši no zemes un atdzīvinājuši, arī nākamajām paaudzēm stāstīs ne tikai par sevi un saviem pētniekiem, bet arī par lietuviešu tautas dēlu Gintautu Česni.

Rita Grāvere, Dr. hist.

Paula Stradiṇa Medicīnas vēstures muzejs 